AperTO - Archivio Istituzionale Open Access dell'Università di Torino

\title{
Chaos and Geodynamics: Mélanges, Mélange-forming Processes and Their Significance in the Geological Record
}

\section{This is the author's manuscript}

Original Citation:

Availability:

This version is available http://hdl.handle.net/2318/121230

since 2016-07-12T19:01:55Z

Published version:

DOI:10.1016/j.tecto.2012.08.002

Terms of use:

Open Access

Anyone can freely access the full text of works made available as "Open Access". Works made available under a Creative Commons license can be used according to the terms and conditions of said license. Use of all other works requires consent of the right holder (author or publisher) if not exempted from copyright protection by the applicable law. 


\section{(4) \\ UNIVERSITÀ DEGLI STUDI DI TORINO}

This Accepted Author Manuscript (AAM) is copyrighted and published by Elsevier. It is posted here by agreement between Elsevier and the University of Turin. Changes resulting from the publishing process - such as editing, corrections, structural formatting, and other quality control mechanisms - may not be reflected in this version of the text. The definitive version of the text was subsequently published in [Tectonophysics, v.568-569, 2012, 1-6, doi: http://dx.doi.org/10.1016/j.tecto.2012.08.002].

You may download, copy and otherwise use the AAM for non-commercial purposes provided that your license is limited by the following restrictions:

(1) You may use this AAM for non-commercial purposes only under the terms of the CC-BY-NC-ND license.

(2) The integrity of the work and identification of the author, copyright owner, and publisher must be preserved in any copy.

(3) You must attribute this AAM in the following format: Creative Commons BY-NC-ND license (http://creativecommons.org/licenses/by-nc-nd/4.0/deed.en),

http://www.journals.elsevier.com/tectonophysics/ 


\title{
Chaos and geodynamics: Mélanges, mélange-forming processes and their significance in the geological record
}

\author{
Yildirim Dilek $^{1-2}$, Andrea Festa $^{3-1}$, Yujiro Ogawa ${ }^{4}$ and Gian Andrea Pini ${ }^{5}$
}

\author{
${ }^{1}$ Department of Geology \& Environmental Earth Science, \\ Miami University, Oxford, $\mathrm{OH} 45056$, USA \\ ${ }^{2}$ School of Earth Science, State Key Laboratory of Geological Processes and \\ Mineral Resources, China University of Geosciences - Beijing, 29 \\ Xueyuan Road, Beijing 100083, P.R. China \\ E-mail address: dileky@muohio.edu \\ ${ }^{3}$ Dipartimento di Scienze della Terra, Università degli Studi di Torino, \\ Via Valperga Caluso, 35, 10125, Torino, Italy \\ E-mail address: andrea.festa@unito.it. \\ ${ }^{4}$ 1-127-2-C-740 Yokodai, Tsukubamirai 300-2358, Japan \\ E-mail address: fyogawa45@yahoo.co.jp. \\ ${ }^{5}$ Dipartimento di Scienze della Terra e Geologico-Ambientali, \\ Università di Bologna, 40127 Bologna, Italy \\ E-mail address: gianandrea.pini@unibo.it.
}

Tectonophysics (2012), v. 568-569, p. 1-6

Special Issue: Chaos and geodynamics: Mélanges, mélange-forming processes and their significance in the geological record

Editors: Dilek., Y., Festa, A., Ogawa, Y., and Pini, G.A. 
Mélanges occur extensively in accretionary and collisional orogenic belts around the world, and represent disrupted and chaotic units including sedimentary, magmatic and metamorphic rocks (commonly as exotic blocks) mixed by stratal disruption and tectonic, diapiric and/or sedimentary processes (Cowan, 1985; Festa et al., 2010; Horton and Rast, 1989; Hsü, 1968; Raymond, 1984; Silver and Beutner, 1980). Although numerous papers and books have been published onmélanges, the definition and the geological significance of mélanges are still a matter of debate and controversy. The mechanisms that are responsible for the formation of mélanges may occur in a range of geological environments from the shallowest geosphere to significant crustal depths, associated with subduction zone tectonics, en-mass sedimentary processes, slope tectonics, in situ fluidization and mud diapirism, strike-slip tectonics, or due to the interplay of some of these processes (Barber and Brown, 1988; Cloos and Shreve, 1988a,b; Festa, 2011; Festa et al., 2010; Harris et al., 1998; Huang et al., 2008; Maltman and Bolton, 2003; Marroni and Pandolfi, 2001; Meschede et al., 1999; Naylor, 1982; Osozawa et al., 2011; Pini et al., 2012; Swarbick and Naylor, 1980; Wakabayashi and Dilek, 2011; Yamamoto et al., 2012).

Although mélanges may characterize diverse geodynamic environments of formation, they are commonly associated with subduction of oceanic lithosphere, collisional events (arc-continent and continentcontinent), and intra-continental deformation including rifting and passive margin evolution (Alonso et al., 2008; Dilek, 2006; Festa et al., 2010). Hence, mélanges are cogenetic with emplacement of ophiolites, advancement of thrust and nappe sheets, evolution of foreland basins, formation of submarine landslides (olistostromes) and seismic events (Festa et al., 2010). Mélange formation is also involved in the mechanical stability of accretionary and orogenic wedges, and in the redistribution of earth materials through the processes of offscraping, underplating, mass-transport movements, subduction channel flow, and mud diapirism (Ogawa, 1998; Shreve and Cloos, 1986; Vannucchi and Bettelli, 2002; Von Huene et al., 2004). Therefore, mélanges and mélange-forming processes are intimately linked with tectonics and tectonically induced geological processes in crustal evolution, and they constitute a significant component of the Earth history. Hence, further systematic and process-oriented, inter-disciplinary studies of mélanges should provide much-needed information about orogenic processes and crustal growth. Furthermore, the results of thesemélange studies should also bemost insightful for the recognition of these chaotic rock bodies in the Precambrian greenstone belts (Dilek and Ahmed, 2003; Dilek and Polat, 2008; Polat et al., 2008).

This Special Issue is a result of series of scientific sessions onmélanges that we convened at the GSA Global Meeting, TECTONIC CROSSROADS, held in Ankara, Turkey in October 2010, the European Geosciences Union General Assembly in Vienna, Austria in May 2010, and the American Geophysical Union Fall Meeting in San Francisco, California, in December 2011. The papers in this Special Issue present the most up-to-date observations and interpretations on various mélange types and mélange forming processes from around the world. The geographic locations of the mélanges covered in this Special Issue are shown in Fig. 1. This Special Issue makes a significant contribution to the mélange concept, streamlines the definitions and classifications ofmélanges and broken formations, and provides a rich archive of welldocumented mélange occurrences from diverse geological environments. We have organized the papers in this Special Issue in six sections, presenting some case studies of various mélange types and different processes of their formation. It is important to note, however, that there are obviously some overlaps among these sections in terms of the mélange types and the related processes described. The first part contains a lead paper providing a new classification of mélanges and broken formations. The next section includes five papers that document the internal structure of the Shimanto accretionary complex and different fabric elements, physical properties and tectonic evolution of various mélange types in this classical accretionary complex. The following part comprises five papers involving mélanges that experienced high-pressure metamorphism and deformation in ancient subduction zones; the special focus here is placed on the Franciscan Complex of California. The next section contains five papers that emphasize the significance of sedimentary and diapiric processes in mélange formation.

Olistostromal mélanges and the processes involved in their formation make up the topic of Part V. The last section contains four papers documenting different case studies of ophiolitic mélanges and the significance of these mélanges for the tectonic construction of the orogenic belts involved.

We thank the contributors to this Special Issue for their time and effort, and express our sincere gratitude to a large number of scientists who provided valuable and timely reviews of the papers in it. We also extend our thanks to the Editor-in-Chief, Dr. Fabrizio Storti, for his editorial help and guidance during the preparation of this special issue, and to the Elsevier staff in the Tectonophysics journal office. 


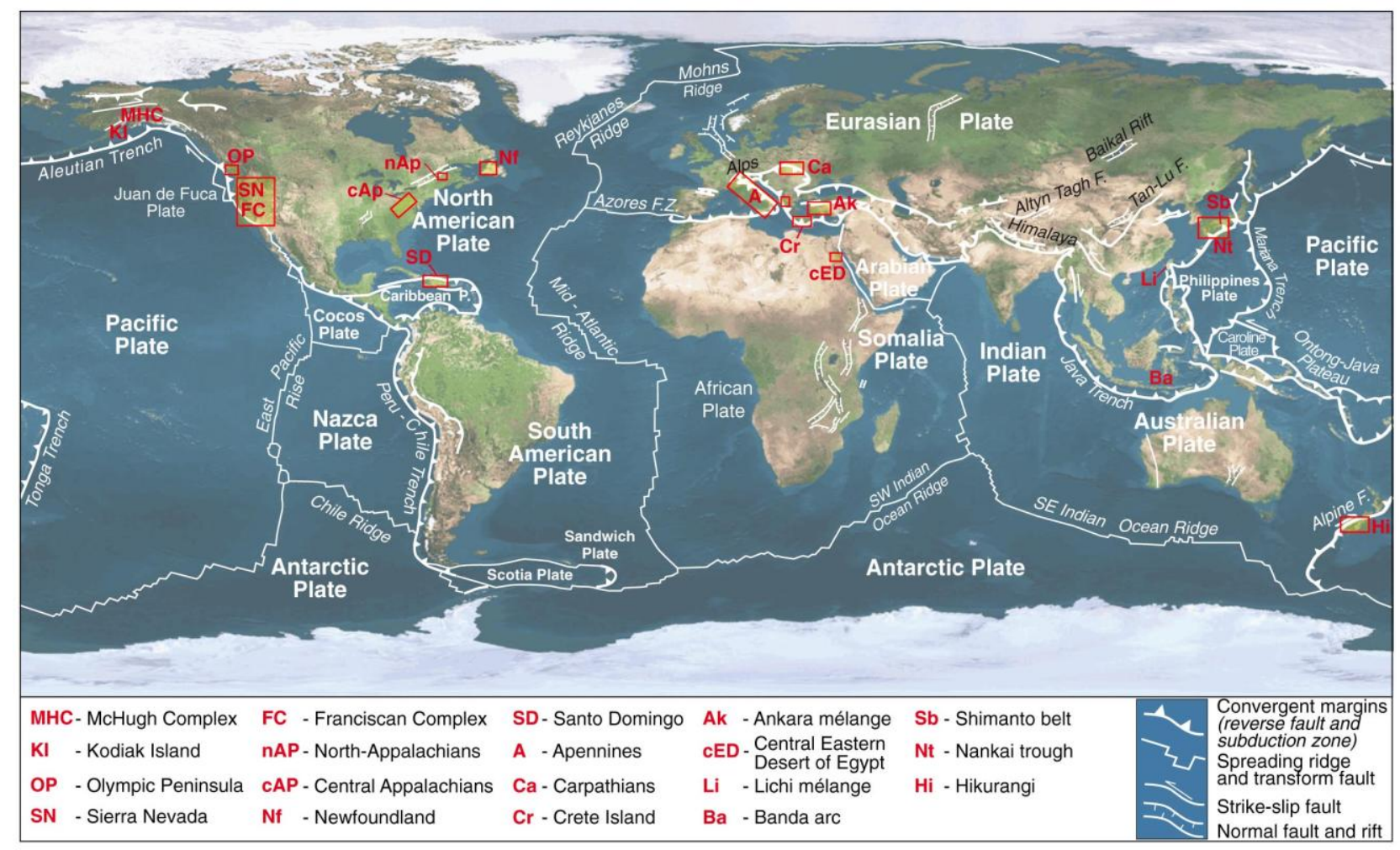

Fig. 1. Relief world map showing the lithospheric plates, their boundaries, major locations of mélange occurrences around the world, and the case studies of mélanges covered by the papers in this special issue (marked by yellow boxes).

\section{Part-I: new classification of mélanges and broken formations}

The term mélange and the mélange concept have evolved significantly since the first use of this term by Edmund Greenly for the Gwna Group of the Mona Complex in Anglesey in North Wales (Greenly, 1919). How mélanges form is still a lively topic of discussion. Thus, a contemporary approach, scrutinizing the historical account of the definition of mélanges and interpreting the mélange terminology is a timely effort. To this end, Festa et al. present a redefinition of mélanges and broken formations and discuss the main mechanisms and processes of stratal disruption and mixing in their development. The authors argue that structures and processes occurring during the generation of mélanges

and broken formations follow a continuum that is controlled, at shallow structural levels, by the increase of the degree of consolidation with burial. With the downward increase of consolidation at depth, the deformation related to tectonic forces becomes gradually more significant. Tectonic events represent the most prominent triggering mechanism inducing, directly or indirectly, different processes of stratal disruption and mixing that produce a broad spectrum of chaotic rock bodies. The authors show that the superposition of different mechanisms and processes of disruption and mixing of rocks in some tectonic settings may lead to reworking of existingmélange products and to the formation of polygenetic mélange types.

\section{Part II: Shimanto Accretionary Complex, SW Japan}

The Cretaceous-Miocene Shimanto accretionary complex occurs extensively in SWand Central Japan, extending from the Boso Peninsula in Kanto to the Nansei Islands, over $1800 \mathrm{~km}$ in length and 100 $\mathrm{km}$ in width (Underwood, 1993; Hara and Kimura, 2008). It is, therefore, a major component of the accretionary history and crustal growth of Japan. The five papers in this section involve various aspects of mélange forming processes during the development of the Shimanto accretionary complex in southwestern Japan. Kimura et al. describe the internal structure of the latest Cretaceous Mugi mélange in the Shimanto Belt that records plate-boundary processes at or near the up-dip limit of the seismogenic zone at several kilometers depth. These authors show that the Mugi mélange initially formed at temperatures of $130-200{ }^{\circ} \mathrm{C}$ 
by cataclastic deformation and tensile cracking of sandstone layers, and by plastic deformation of the dehydrated clayey-shale matrix. Subsequent peeling off and underplating of the downgoing oceanic basement made a pile of thrust sheets producing a tectonic mélange. A pseudotachylyte outcrop occurs along the roof thrust of the Mugi mélange, whereas a fluidized ultracataclasite showing evidence of heating occurs at the interface between the subducting oceanic slab and the mélange. The significance of these observations is that the mélange itself represents a "fault rock" along a convergent plate boundary displaying a record of various types of paleo-earthquakes in a subduction zone setting.

Kitamura and Kimura examine the internal structure of three mélange occurrences in the Shimanto Belt and evaluate the record of their progressive deformation processes with subduction within a seismogenic zone. The authors document the deformation structures in sandstone blocks and the strain history of the shale matrix of these mélanges, and discuss the nature of deformation partition through space and time in the seismogenic zone. They, then, discuss the spatiotemporal relationships between tectonic mélange formation and interseismic processes of mega earthquake occurrences.

Tokiwa and Yamamoto report the magnetic fabrics of a tectonic mélange in the Miyama Formation of the Shimanto Belt, and correlate the obtained data with the shear directions estimated from traditional measurements of $\mathrm{P}-\mathrm{Y}$ intersections in the mélange. The authors show that the maximum magnetic susceptibility (Kmax) axes are commonly oriented parallel to the direction of shear on the shear planes or parallel to the $\mathrm{P}-\mathrm{Y}$ intersections, thus providing a significant tool for determining shear directions in mélanges. In both the cases, minimum magnetic susceptibility (Kmin) axes are oriented perpendicular to mélange foliation. This observation in turn suggests that the restored shear direction deduced from anisotropy of magnetic susceptibility (AMS) data can be used effectively to decipher the kinematics of ancient plate motions at convergent boundaries.

Yamamoto et al. present a series of fabric-based criteria to distinguish between tectonic and sedimentary mélanges with examples from the Shimanto Belt exposed in the Yakushima Island, SW Japan. They show that sedimentary mélanges are characterized by fabric elements that were a result of compaction and diagenesis, and that the patterns of magnetic ellipsoids obtained from such mélanges represent a cleavage/bedding-parallel magnetic foliation. The AMS data obtained from tectonic mélanges and duplex structures show a less intense magnetic foliation compared to those from sedimentary mélanges, with the maximum magnetic susceptibility (Kmax) axes oriented parallel to the intersection between S- and C-planes and to the long axis of pencil cleavage. These features may provide significant tools in mélange studies and in differentiating progressive stages of mélange formation during the overall history of sediment deposition, burial, accretion, and uplift in accretionary complexes.

Wakita documents some of the mappable features of mélanges in the Jurassic accretionary complexes of the Mino and Chichibu terrains in Southwest Japan, and shows that these structures formed as a result of submarine sliding, diapirism, and tectonic shearing along decollement, offscraping, underplating, and/or out-of-sequence thrust planes. One common aspect of the mélanges examined in this paper is that they all consist of sandstone, conglomerate, mudstone, siliceous shale, chert, limestone and basalt that collectively form a single lithostratigraphic succession representing an Ocean Plate Stratigraphy.

\section{Part III: mélanges with high pressure overprint}

Mélanges containing high-pressure (an in some cases ultra highpressure) rocks and occurring in accretionary complexes provide significant information about the mechanisms of these rocks and their PTt paths in subduction channels (Cloos, 1982; Federico et al., 2007; Gerya et al., 2002; Hermann et al., 2000). This section includes five papers involving mélanges displaying structural and petrological evidence for high-pressure metamorphism and deformation in ancient subduction zones. A particular emphasize is given to the Franciscan Complex of California as an archetype accretionary complex in the world. Grigull et al. in the first paper evaluate the effect of block volume fraction and block size frequency on the bulk rheology of a block-in-matrix structure in high-pressure/low-temperature mélange types, specifically the Franciscan Complex (California), the Rio San Juan Complex (Dominican Republic), and the Diahot Unit (NewCaledonia). The authors use microscopic observations to show that dissolution-precipitation creep is the predominant deformation mechanism in the HP-LT matrix rocks, and they infer that the matrix can be approached as a linear viscous Newtonian fluid. Their modeling suggests that deformation may be entirely taken up by the matrix while blocks remain floating without significant further deformation, likely to be reminiscent of -as a first approximation-the interior of a subduction channel at depth. 
Malatesta et al. report that the Voltri Massif in the Ligurian-Piemontese Units of the Western Alps, Italy, contains serpentinites and metasedimentary rocks enclosing variably deformed lenses of metagabbro, metabasite and peridotite rocks. All these mafic-ultramafic rocks display mineral and textural evidence for heterogeneousmetamorphic peak conditions, ranging fromeclogite to blueschist facies, characteristic of different depths during the Alpine subduction. The authors show that there exists a strong strain partitioning between the highly deformed matrix (serpentinite and metasedimentary rocks) and the more competent blocks of varying sizes (e.g. metagabbro and metaperidotite), suggesting that the Voltri Massif rocks were probably exhumed inside a serpentinite-subduction channel. Serpentinites might have enhanced the exhumation of HP-rocks by lowering the bulk density of subducted material and by establishing a lowviscosity channel between the lower and upper plates.

Hitz and Wakabayashi document the occurrence of an unmetamorphosed sedimentary mélange developed in a nascent forearc basin setting in the San Francisco Bay region of coastal California. They demonstrate that the mélange contains blocks of high-pressure metamorphic rocks derived from the Franciscan subduction complex as well as blocks of the Great Valley Group forearc basin strata and the Coast Range Ophiolite in a matrix composed of foliated shale and serpentinite. They argue that the exhumation and deposition of Franciscan blocks in the nascent forearcmélange predates the accretion of similar materials in the adjacent Franciscan Complex by at least 30 m.y., suggesting subduction erosion of the previously accreted material, or exhumation of the blocks in forearc serpentinite-shale diapirs.

Wassmann and Stöckhert examine the microstructural record of a highly deformed, schistose and foliated, compositionally heterogeneous jadeite blueschist, belonging to the Franciscan Complex exposed on Angel Island. They argue that this rock provides significant insights into the mechanisms of deformation localized in thematrix of a tectonic mélange, specifically the contribution of crystalline plasticity versus dissolution and precipitation on grain scale, and the role of fracturing and vein formation. Because the jadeite blueschist was exhumed from depths of $>30-45 \mathrm{~km}$ without any subsequent deformation overprint, the authors infer that the block-in-matrix structure in the mélange of the Franciscan Complex may reflect the properties and processes in a deep subduction channel, allowing us to estimate the flow stress and rheological behavior along the plate interface at depth.

Ukar presents a tectonic model for the origin, metamorphism, and exhumation of high-P rocks as blocks in a shale matrix in the Central Belt of the Franciscan Complex. She suggests that the blocks embedded in the shale-matrix were once part of a coherent terrane accreted at the base of the North American plate. During the initial stages of Franciscan subduction, part of the volcanic sequence and overlying sediments were under-plated at the bottom of the overriding plate and were metamorphosed under high-P conditions. Shallowing of the subducting Farallon plate around $80 \mathrm{Ma}$ resulted in the exhumation of the HP rocks and in the extensional thinning of the leading edge of the hangingwall. Blocks of blueschist rockswere then plucked fromthe bottomof the overriding plate and incorporated into the subduction channel shear zone, in which they were extended, boudinaged, metasomatically altered, and cataclastically deformed during their uplift to the surface. Ukar proposes that this exhumation process was facilitated by gravitydriven, seaward-oriented extensional thinning of the forearc prism, caused by a decrease in the dip angle of the subducting slab that began $\sim 80 \mathrm{Ma}$.

\section{Part IV: sedimentary and diapiric processes in mélange formation}

Chaotic tectonostratigraphic units in some orogenic wedges containrock blocks of various size, origin, age, and lithology commonly embedded in a sedimentary matrix by sedimentary and/or diapiric processes. These deposits undergo continuous deformation during the wedge growth and hence keep an intact structural record of the dynamic evolution of a wedge. This section includes five papers on different examples of sedimentary and diapiric mélanges and related processes involved in their formation in accretionary wedges. In the first paper, Codegone et al. report on the occurrence of small-scale polygenetic mélanges in the Ligurian accretionary complex in the Northern Apennines of Italy, and discuss the role of shale diapirism in superposed mélange evolution in orogenic belts. They show, based on detailed, thematic mapping of the stratigraphy and structures, that the Argillevaricolori (Varicolored scaly clays) of the External Ligurian Units contain diverse types of small-scale mélanges forming a composite chaotic unit, in which the complex interplay of tectonic, sedimentary and diapiric processes produced polygenetic mélanges. The internal structure and spatial-temporal relationships of these mélanges display a record of the progressive evolution of the Ligurian accretionary wedge from subduction to collision and intra-continental deformation. 
Ogata et al. report on case studies of mass transport-related disruption processes and their artifacts within sedimentary mélanges from the early Oligocene wedge-top deposits in the northern Apennines (Italy) and the Eocene foredeep carbonate megabreccias from the southcentral Pyrenees (Spain). These mass transport deposits have an unsorted, strongly mixed, and relatively fine-grained clastic matrix, infilling the space between large clasts and blocks. The matrix displays either simple shear related structures or a massive, homogeneous fabric, both likely related to liquefaction/fluidization processes. The down-slope movement during mass transport is accompanied by the development of ductile, overpressured shear zones, both internally and along the basal decollement. This matrix signature hence represents a significant feature to distinguish sedimentary and tectonic mélanges within accretionary complexes.

Perotti et al. present a case study of an Eocene sedimentary mélange occurring in the Provençal Dauphinois Domain in the Western Ligurian Alps. The mélange consists of debris flow paraconglomerates, breccias, and up to km-size megablocks that are interbedded with fine-grained turbiditic rocks. The authors argue that extensive, syn-depositional transcurrent faulting during the late Eocene and early Oligocene in the Dauphinois domain of the Alpine foreland basin was responsible for triggering mass gravity flows as well as exposing/exhuming older rocks around and across the basin. Fluid expulsion, mass wasting, and burial compaction were other significant processes that controlled the sedimentary mélange formation in the area.

Codegone et al. document that the Hamburg Klippe exposed in the Central Appalachian orogenic belt in eastern Pennsylvania displays a complex record of poly-phase mélange and broken formation development in a convergent margin setting. The mélanges they have differentiated display a complete record of subduction to collision tectonics, and the main processes that strongly controlled their formation include the degree of consolidation of the layered strata and their rheological differences, the structural level of mélange formation within an accretionary wedge, and the kinematics of deformational processes.

Wakabayashi presents a complex record of burial-exhumation cycles of sedimentary serpentinite mélanges from the Franciscan Complex in California and reports exhumation rates ranging from $1.2 \mathrm{~mm} / \mathrm{yr}$ to $10 \mathrm{~mm} / \mathrm{yr}$. The oldest Franciscan serpentinite mélanges appear to be $\sim 35 \mathrm{~m}$.y. younger than sedimentary serpentinites of the overlying Great Valley Group (GVG) forearc basin deposits. Subduction erosion may have facilitated reworking of forearc sedimentary serpentinite deposits into the trench. The occurrence of multiple burial exhumation cycles in the Franciscan Complex indicates the significance of reworking of subduction complex material at convergent margins.

\section{Part V: olistostromal mélanges}

The term olistostrome describes a sedimentary deposit comprised of a chaotic mass of rock blocks and mud, put together by gravity mass flows of unconsolidated sediments in submarine environments (Abbate et al., 1981; Lucente and Pini, 2003). These deposits accumulate in a semifluid condition and hence generally lack bedding structures. Olistostromes and olistostromal mélanges generally form in seismically active geological settings where the formation of submarine slides, rock falls, debris flows and in situ liquefaction is common (Brandon, 1989). Pervasive stratal disruption, layer-parallel fragmentation and intermixing of olistostromes in these types of mélanges are not tectonic in origin but owe their formation mainly to gravitational and sedimentary processes. This section includes five papers on olistostromal mélange occurrences in different orogenic belts, discussing their internal structure and evolution.

The paper by Cieszkowski et al. reports the olistostrome formations as sub-marine debris flow and avalanche deposits during the evolution of the proto-Silesian and Silesian basins in the Outer West Carpathians. Olistostrome formation here spanned multiple phases with different tectonic processes, including an extensional tectonic regime during the late Cretaceous, a contractional regime during the late Cretaceous through the Paleocene, and the accretionary wedge evolution during the Eocene and early Oligocene. The authors argue that the lithological compositions and structures of olistostromal deposits can provide significant clues about the basin margins, which may have been destroyed by subsequent orogenic events.

Huerta et al. document, based on the results of an extensive 50,000 scale mapping project, the distribution of mélanges and olistostromes in the Puerto Plata area in northern Dominican Republic. They discuss the formation of these mélanges as a result of mostly sedimentary processes in subduction zone settings and of the collisional processes between the Caribbean and North American plates during the late Cretaceous to early Paleogene. Significant strike-slip deformation due to the ongoing oblique collision since the early Paleogene has modified and/or obliterated the original stratigraphic and structural relationships in the area, and hence it is difficult to reconstruct the precise tectonic history of the mélange formations. 
Okay et al. present an olistostromal mélange occurrence in western Turkey that consists mainly of gravity mass flow deposits. Significantly affected by transcurrent faulting during its formation, this mélange, the Bornova Flysch Zone, received ophiolitic and accretionary prism material from an active collision zone to the ESE.

Prohoroff et al. report that sandstone matrix olistostromes and sedimentary mélanges may constitute a larger part of the Franciscan Complex than previously recognized, and that the introduction of Franciscan exotic blocks and development of Franciscan block-in-matrix fabrics may have largely occurred through sedimentary sliding. Their age data show that the bulk of the detrital material comprising the olistostromal units was derived by exposure and sedimentary recycling of significantly older, previously accreted sediments.

Ślączka et al. present a comparative study of sedimentary basin and olistolith formation in the Polish Carpathians (late Jurassic to early Miocene) and in the Apenninic-Maghrebian mountain chain of Sicily (Triassic-Miocene). The sedimentary basin evolution in these two regions shares a common geological background: both basins initially developed as a result of extensional tectonics and associated rifting of carbonate platforms. Olistolith blocks and olistostromes were derived from the rift shoulders in the beginning and then from the intrabasinal tectonic ridges in the advanced stages of basin evolution. Basin inversion due to compressional tectonics at the latest stage was also important in both regions for olistostrome development.

\section{Part VI: ophiolitic mélanges}

Ophiolitic mélanges are spatially and temporally associated with ophiolite nappes in orogenic belts (Dilek and Furnes, 2011; Gansser, 1974; Altunkaynak and Dilek, 2006), and may display a complex record of the rift-drift, seafloor spreading and subduction zone tectonic evolution of the associated ophiolites (Dilek et al., 1999, 2005, 2007; Dilek and Robinson, 2003; Dilek and Furnes, 2009). They may occur as subophiolitic or supra-ophiolitic (overlying the ophioltes) in origin, and their matrix may range in composition from serpentinite, serpentinite mud, greywacke, turbiditic rocks, and mud-shale (Dilek and Thy, 2006; Furnes et al., 2012; Phipps, 1984; Saleeby, 1984; Shervais et al., 2011). The final configuration and development of the structural architecture of ophiolitic mélanges are strongly controlled by ophiolite emplacement and collisional (arc-continent, continent-continent) processes (Dilek, 2006; Dilek and Furnes, 2011; Flower and Dilek, 2003; Furnes et al., 2012; Robertson et al., 2009). This section contains four papers involving a wide range of age and geographic location regarding the ophiolitic mélange occurrences around the world.

Tortorici et al. discuss the internal structure and tectonic significance of an ophiolitic mélange in Crete as an accretionarywedge complex. The Cretan ophiolitic mélange consists of three structural units with different metamorphic overprint: a lower unit of weakly metamorphosed rocks, a middle unit of greenschist to HP greenschist metamorphic rocks, and an upper unit of blueschist facies metamorphic rocks. All three units include both oceanic and continentally-derived rocks. The final stacking of these tectonic units and the structural architecture of the Cretan mélange were strongly affected by the collision tectonics that started in the early Middle Eocene.

Elitok examines the internal structure and geochemistry of allochthonous rock units in the Antalya Complex exposed within the northern apex of the Isparta Angle in SW Turkey. These units include slope basin deposits associated with the Upper Triassic alkali basalt and trachyandesite volcanic rocks, Upper Jurassic-Lower Cretaceous tholeiitic volcanic rocks, olistostromal and sub-ophiolitic mélanges, and peridotite slabs that are intruded by doleritic dike swarms. These rocks collectively record a rift-drift, seafloor spreading and subduction zone tectonics of a narrow Tethyan ocean basin that opened up from south to north, and the mélange units were stacked up during the closure of this basin and ophiolite emplacement.

El Bahariya documents different occurrences of Neoproterozoic ophiolitic mélanges in the Central Eastern Desert of Egypt. Based on structural field observations, geochemical data, and regional tectonic constraints, he concludes that ophiolitic rocks in these mélanges represent fragments of oceanic lithosphere that formed in a back-arc/arc environment. These oceanic fragments were incorporated into the mélanges through tectonic and sedimentary processes.

Zagorevski et al. present a comprehensive study of the Dunnage Mélange along the main Iapetus suture in the Newfoundland Appalachians, and conclude that tectonic deformationwas a major component in its genesis. The Dunnage Mélange includes a chaotic, heterogeneous assemblage of unsorted blocks embedded in a fine-grained matrix. The authors interpret that this mélange originally formed on the 
Victoria-Penobscot arc crystalline forearc basement, rather than in an arctrench gap or in a backarc setting as previously suggested.

\section{References}

Abbate, E., Bortolotti, V., Sagri, M., 1981. Excursion no 5: olistostromes in the Oligocene Macigno formation (Florence area), introduction: an approach to olistostrome interpretation. In: Ricci Lucchi, F. (Ed.), International Association of Sedimentologists,2nd European Regional Meeting, Bologna, 1981, Excursion Guidebook, Tecnoprint,

Bologna, pp. 165-185.

Alonso, J.L., Gallastegui, J., García-Sansegundo, J., Farias, P., Rodrìguez Fernández, L.R.,Ramos, V.A., 2008. Extensional tectonics and gravitational collapse in an Ordovician passive margin: the Western Argentine Precordillera. Gondwana Research 13,204-215.

Altunkaynak, S., Dilek, Y., 2006. Timing and nature of post-collisional volcanism inwestern Anatolia (Turkey) and geodynamic implications. Geological Society of America Special Paper 409, 321 351. http://dx.doi.org/10.1130/2006.2409(17).

Barber, T., Brown, K., 1988. Mud diapirism: the origin of melanges in accretionary complexes? Geology Today 4, 89-94.

Brandon, M.T., 1989. Deformational styles in a sequence of olistostromal mélanges, Pacific Rim Complex, western Vancouver Island, Canada. Geological Society of America Bulletin 101, 1520-1542.

Cloos, M., 1982. Flow mélanges: numerical modeling and geologic constraints on their origin in the Franciscan subduction complex, California. Geological Society of America Bulletin 93, 330 345 .

Cloos, M., Shreve, R.L., 1988a. Subduction-channel model of prismaccretion, melange formation, sediment subduction, and subduction erosion at convergent plate margins: 1. Background and description. Pure and Applied Geophysics 128 (3-4), 455-500.

Cloos,M., Shreve, R.L., 1988b. Subduction-channel model of prismaccretion,mélange formation, sediment subduction, and subduction erosion at convergent plate margins: 2. Implications and discussion. Pure and Applied Geophysics 128 (3-4), 501-545.

Cowan, D.S., 1985. Structural styles in Mesozoic and Cenozoic mélanges in the western Cordillera of North America. Geological Society of America Bulletin 96, 451-462.

Dilek, Y., 2006. Collision tectonics of the Eastern Mediterranean region: causes and consequences. Geological Society of America Special Paper 409, 1-13. http://dx.doi.org/10.1130/2006.2409(1).

Dilek, Y., Ahmed, Z., 2003. Proterozoic ophiolites of the Arabian Shield and their significance in Precambrian tectonics. In: Dilek, Y. and Robnson, P.T. (Eds.), Ophiolites in Earth History: Geological Society of London Special Publication, 218, pp. 685-701.

Dilek, Y., Thy, P., 2006. Age and petrogenesis of plagiogranite intrusions in the Ankara Mélange, Central Turkey. Island Arc 15, 44-57. http://dx.doi.org/10.1111/j.1440-1738.2006.00522.x.

Dilek, Y., Robinson, P.T., 2003. Ophiolites in Earth history. In, Geological Society of London Special Publication 218, 1-8. http://dx.doi.org/10.1144/GSL.SP.2003.218.01.01.

Dilek, Y., Polat, A., 2008. Suprasubduction zone ophiolites and Archean tectonics. Geology 36, 430-432. http://dx.doi.org/10.1130/Focus052008.1. 
Dilek, Y., Furnes, H., 2009. Structure and geochemistry of Tethyan ophiolites and their petrogenesis in subduction rollback systems. Lithos 113, 1-20. http://dx.doi.org/10.1016/j.lithos.2009.04.022.

Dilek, Y., Thy, P., Hacker, B., Grundvig, S., 1999. Structure and petrology of Tauride ophiolites and mafic dike intrusions (Turkey): implications for the Neotethyan ocean. Geological Society of America Bulletin 111, 1192-1216. http://dx.doi.org/10.1130/00167006(1999)111b1192:SAPOTO>2.3.CO;2.

Dilek, Y., Shallo, M., Furnes, H., 2005. Rift-drift, seafloor spreading, and subduction zone tectonics of Albanian ophiolites. International Geology Review 47, 147-176.

Dilek, Y., Furnes, H., Shallo, M., 2007. Suprasubduction zone ophiolite formation along the periphery of Mesozoic Gondwana. Gondwana Research 11, 453-475.

Dilek, Y., Furnes, H., 2011. Ophiolite genesis and global tectonics: geochemical and tectonic fingerprinting of ancient oceanic lithosphere. The Geological Society of America Bulletin 123, 387-411. http://dx.doi.org/10.1130/B30446.1.

Federico, L., Crispini, L., Scambelluri, M., Capponi, G., 2007. Ophiolite melange zone records exhumation in a fossil subduction channel. Geology 35, 499-502.

Festa, A., 2011. Tectonic, sedimentary, and diapiric formation of the Messinian mélange: tertiary Piedmont Basin (northwestern Italy). In: Wakabayashi, J., Dilek, Y. (Eds.), Mélanges: processes of formation and societal significance: Geological Society of America Special Papers, 480, pp. 215-232. http://dx.doi.org/10.1130/2011.2480(10).

Festa, A., Pini, G.A., Dilek, Y., Codegone, G., 2010.Mélanges andmélange forming processes: historical overview and new concepts. International Geology Review 52, 1040-1105. http://dx.doi.org/10.1080/002068109035557704.

Flower, M.F.J., Dilek, Y., 2003. Arc-trench rollback and forearc accretion: 1. A collisioninduced mantle flow model for Tethyan ophiolites. Ophiolites in Earth History: Geological Society of London Special Publication, 218, pp. 21-42.

Furnes, H., Dilek, Y., Pedersen, R.B., 2012. Structure, geochemistry, and tectonic evolution of trench-distal backarc oceanic crust in the western Norwegian Caledonides, Solund-Stavfjord ophiolite (Norway). Geological Society of America Bulletin 124, 1027-1047. http://dx.doi.org/10.1130/B30561.1.

Gansser, A., 1974. The ophiolitic mélange, a world-wide problem on Tethyan examples. Eclogae Geologicae Helvetiae 67, 479-507.

Gerya, T.V., Stöckhert, B., Perchuk, A.L., 2002. Exhumation of high-pressure metamorphic rocks in a subduction channel: a numerical simulation. Tectonics 21, 1056. http://dx.doi.org/10.1029/2002TC001406.

Greenly, E., 1919. The Geology of Anglesey: Great Britain Geological Survey Memoir 1, pp. 980.

Hara, H., Kimura, K., 2008. Metamorphic and cooling history of the Shimanto accretionary complex, Kyushu, Southwest Japan: implications for the timing of out-of-sequence thrusting. Island Arc 17, 546-559.

Harris, R.A., Sawyer, R.K., Audley-Charles, M.G., 1998. Collisional mélange development: geologic association of active mélange-forming processes with exhumed mélange facies in the western Banda orogen, Indonesia. Tectonics 17 (3), 458-479. 
Hermann, J., Muuntener, O., Scambelluri, M., 2000. The importance of serpentinite mylonites for subduction and exhumation of oceanic crust. Tectonophysics 327, 225-238.

Horton Jr., J.W., Rast, N. (Eds.), 1989. Mélanges and olistostromes of the Appalachians: Geological Society of America Special Papers, 228, p. 276.

Hsü, K.J., 1968. Principles of mélanges and their bearing on the Franciscan-Knoxville Paradox. Geological Society of America Bulletin 79, 1063-1074.

Huang, C.Y., Chien, C.W., Yao, B., Chang, C.P., 2008. The LichiMélange: a collisional mélange formation along early arcward backthrusts during forearc basin closure, Taiwan arc continent collision. In: Draut, A.E., Clift, P.D.O., Scholl, D.W. (Eds.), Geological Society of America Special Papers, 436, pp. 127-154.

Lucente, C.C., Pini, G.A., 2003. Anatomy and emplacement mechanism of the large submarine slide within the Miocene foredeep in the Northern Apennines, Italy: a field perspective. American Journal of Science 303, 565-602.

Maltman, A.J., Bolton, A., 2003. How sediments become mobilized. Geological Society, London, Special Publications 216, 9-20. http://dx.doi.org/10.1144/GSL.SP.2003.216.01.02.

Marroni, M., Pandolfi, L., 2001. Debris flow and slide deposits at the top of the Internal Liguride ophiolitic sequence, Northern Apennines, Italy: a record of frontal tectonic erosion in a fossil accretionary wedge. Island Arc 10, 9-21.

Meschede, M., Zweigel, P., Frisch, W., Völker, D., 1999. Mélange formation by subduction erosion: the case of the Osa mélange in southern Costa Rica. Terra Nova 11, 141-148.

Naylor, M.A., 1982. The Casanova Complex of the Northern Apennines: a mélange formed on a distal passive continental margin. Journal of Structural Geology 4, 1-18.

Ogawa, Y., 1998. Tectonostratigraphy of the Glen App area, Southern Uplands, Scotland: anatomy of Ordovician accretionary complex. Journal of the Geological Society of London 155, 651-662.

Osozawa, S., Pavlis, T., Flowers, M.F.J., 2011. Sedimentary block-in-matrix fabric affected by tectonic shear, Miocene Nabae complex, Japan. In: Wakabayashi, J., Dilek, Y. (Eds.), Mélanges: Processes of Formation and Societal Significance: Geological Society of America Special Papers, 480, pp. 189-206. http://dx.doi.org/10.1130/2011.2480(08).

Phipps, S.P., 1984. Ophiolitic olistostromes in the basal Great Valley sequence, Napa County, northern California Coast Ranges. Geological Society of America Special Papers 198, 103-125.

Pini, G.A., Ogata, K., Camerlenghi, A., Festa, A., Lucente, C.C., Codegone, G., 2012. Sedimentary mélanges and fossil mass-transport complexes: a key for better understanding submarine mass movements. In: Yamada, Y., et al. (Ed.), Submarine mass movements and their consequences: advances in natural and technological hazards research, 31. Springer Science+Business Media B.V., pp. 585-594.

Polat, A., Frei, R., Appel, P.W.U., Dilek, Y., Fryer, B., Ordonez-Calderon, J.C., Yang, Z., 2008. The origin and compositions of Mesoarchean oceanic crust: evidence from the 3075 Ma Ivisaartoq greenstone belt, SW Greenland. Lithos 100, 293-321. http://dx.doi.org/10.1016/j.lithos.2007.06.021. 
Raymond, L.A., 1984. Classification of melanges. In: Raymond, L.A. (Ed.), Melanges: their nature, origin and significance: Geological Society of America Special Papers, 198, pp. 7-20. Boulder, Colorado.

Robertson, A.H.F., Parlak, O., Ustaömer, T., 2009. Mélange genesis and ophiolite emplacement related to subduction of the northernmargin of the Tauride Anatolide continent, central and western Turkey. Geological Society, London, Special Publications 311, 9-66.

Saleeby, J., 1984. Tectonic significance of serpentinite mobility and ophiolitic melange. In: Raymond, L.A. (Ed.), Their Nature, Origin, and Significance: Geological Society of America Special Papers, 198, pp. 153-168.

Shervais, W.J., Choi, S.H., Sharp, W.D., Ross, J., Zoglman-Schuman, M., Mukasa, S.B., 2011. Serpentinite matrix mélange: implications of mixed provenance for mélange formation. In: Wakabayashi, J., Dilek, Y. (Eds.), Geological Society of America Special Papers, 480, pp. 1-30. http://dx.doi.org/10.1130/2011.2480(01).

Shreve, R.L., Cloos, M., 1986. Dynamics of sediment subduction, mélange formation, and prism accretion. Journal of Geophysical Research 91, 10229-10245. Silver, E.A., Beutner, E.C., 1980. Melanges. Geology 8, 32-34.

Swarbick, R.E., Naylor, M.A., 1980. The Kathikas melange, SW Cyprus: late Cretaceous submarine debris flows. Sedimentology 27, 63-78.

Underwood, M.B. (Ed.), 1993. Thermal evolution of the Tertiary Shimanto Belt, Southwest Japan: An example of ridge-trench interaction. Geological Society of America Special Paper 273, 179 p.

Vannucchi, P., Bettelli, G., 2002. Mechanism of subduction accretion as implied from the broken formations in the Apennines, Italy. Geology 30, 835-838.

von Huene, R., Ranero, C.R., Vannucchi, P., 2004. Generic model of subduction erosion. Geology 32, 913916.

Wakabayashi, J., Dilek, Y., 2011. Introduction: characteristics and tectonic settings of melanges, and their significance for societal and engineering problems. In: Wakabayashi, J., Dilek, Y. (Eds.), Melanges: Processes of Formation and Societal Significance: Geological Society of America Special Papers, 480, pp. V-x. http://dx.doi.org/10.1130/2011. 2480(00).

Yamamoto, Y., Yamada, Y., Yamashita, Y., Chiyonobu, S., Shibata, T., Hojo, M., 2012. Systematic development of, submarine slope failures at subductionmargins: fossil record of accretionrelated slope failure in the Miocene Hota Accretionary Complex, Central Japan. In: Yamada, Y. (Ed.), Submarinemassmovements and their consequences: Advances in natural and technological hazards research, 31. Springer Science+Business Media B.V, pp. 355-364. 